\title{
Pollen morphology of the genus Aruncus L. (Rosaceae)
}

\author{
Min-Kyoung Ok and Suk-Pyo Hong* \\ Laboratory of Plant Systematics, Department of Biology, Kyung Hee University, Seoul, 02447, Korea
}

(Received 11 November 2015; Revised 8 December 2015; Accepted 9 December 2015)

\section{개승마속(Aruncus L., 장미과)의 화분형태학적 연구 \\ 옥민경 · 홍석표* \\ 경희대학교 이과대학 생물학과}

\begin{abstract}
Pollen morphological characteristics of 7 taxa of the genus Aruncus L. (Rosaceae) were examined using scanning electron microscopy (SEM) to evaluate the taxonomic implication within the genus. Aruncus pollen grains were monad, tri-colporate with granular membranes, small in size $(\mathrm{P}=8.33-12.57 \mu \mathrm{m}, \mathrm{E}=8.93-14.40 \mu \mathrm{m})$, amb is sub-circular to circular, suboblate to prolate-spheroidal in shape $(\mathrm{P} / \mathrm{E}=0.68-1.70)$. The sexine ornamentation in all studied taxa was basically striate but existence of perforation (striate-perforate: A. dioicus, A. dioicus var. acuminatus, A. dioicus var. astilboides, A. dioicus var. pubescens, $A$. dioicus var. vulgaris; striate-pstilate: $A$. dioicus var. aethusifolius, $A$. gombalanus) and the widths of muri and grooves varied according to the taxa. In particular, relatively short, and sharply crested muri being a distinct feature of $A$. dioicus var. acuminatus. As a result, the various combination of each pollen characteristics could be useful to identify the some taxa of the genus Aruncus.
\end{abstract}

Keywords: Aruncus, Rosaceae, SEM, Pollen morphology, Sexine ornamentation, Principal Components Analysis (PCA)

적 요: 개승마속 내 7 분류군이 갖는 화분형태학적 형질변이의 분류학적 유용성을 알아보기 위하여 주사전 자현미경을 사용하여 자세히 관찰하였다. 본 속의 화분은 단립으로 크기는 소립 $(\mathrm{P}=8.33-12.57 \mu \mathrm{m}$, $\mathrm{E}=8.93-14.40 \mu \mathrm{m})$ 이며, 극축면에서는 아원형에서 원형의 형태를, 적도면에서는 아단구형에서 약장구형에 걸친 형태를 나타내고 $(\mathrm{P} / \mathrm{E}=0.68-1.70)$, 과립상 돌기를 지닌 3 공구형의 발아구를 갖는 것으로 확인되었다. 화 분의 표면무늬는 기본적으로 유선상의 특징을 지니고 있으나, 천공의 유무, 유선과 유선 사이의 너비 등에서 는 차이를 보여주었다. 특히, A. dioicus var. acuminatus는 속내의 다른 분류군에 비해서 상대적으로 짧고 높 게 솟아있는 유선을 갖는 특징으로 구분됨을 확인하였다. 화분학적 형질을 종합한 결과, 개승마속의 다양한 화분학적 변이의 조합은 속 내 일부 분류군을 구별하는데 유용한 것으로 나타났다.

주요어: 개승마속, 장미과, 주사전자현미경, 화분형태, 화분표면무늬, 주성분분석

\section{Introduction}

The genus Aruncus L. (tribe Spiraeeae DC., subfamily Spiraeoideae Agardh., family Rosaceae Juss.) contains 10 taxa (2 species, 5 varieties, 3 formae) distributed throughout the

\footnotetext{
*Author for correspondence: sphong@khu.ac.kr
}

http://www.pltaxa.or.kr

Copyright (C) 2015 the Korean Society of Plant Taxonomists temperate regions of Northern Hemisphere (Tutin, 1964; Ikeda, 1995). Consistently belonging to the subfamily Spiraeoideae, Aruncus is a well-defined genus, characterized by herbaceous habit, follicle without bristles, and absence of epicalyx (Tutin, 1964; Ikeda, 1995; Potter et al., 2007). Taxa within Aruncus have been classified according to external morphological characters such as leaf shape; panicle density; and length of the petals, style, and follicle (Hara, 1955; Mellichamp, 1976). However, according to the Hara (1955)'s concept, it is better to treat Aruncus as a monotypic genus due to the high degree of 
variability in these characters (Hara, 1955; Mellichamp, 1976; Ikeda, 1995). He designated $A$. dioicus (Walter) Fernald as a type species of this genus, however, according to the most recently accepted classification, 5 varieties and 3 formae are recognized within this species, and A. gombalanus (Hand.Mazz.) Hand.-Mazz. has been accepted as another distinct species within the genus (The Plant List, 2013, version 1.1., Published on the Internet; http://www.theplantlist.org/). In fact, within the genus Aruncus, morphological diagnostic characteristics are ambiguous between and within taxa.

One way to examine ambiguous taxonomic relationships is to study a relatively conservative characteristic such as pollen morphology (Hebda and Chinnappa, 1990b). Pollen morphology is diverse, and is widely accepted to reflect phylogenetic relationships (Lee et al., 2011). It has been used to discriminate genera and/or species, and in the Rosaceae, sexine ornamentation is a particularly informative feature (Reitsma, 1966; Thakur and Thakur, 1970; Hebda et al., 1988a, b; Hebda and Chinnappa, 1990a, b; Polyakova and Gataulina, 2008; Chung et al., 2010; Wroñska-Pilarek and Jagodziñski, 2011; Shi et al., 2013). Hebda and Chinnappa (1994) classified rosaceous pollen types using sexine ornamentation patterns and described the pollen grain of Aruncus dioicus (Walter) Fernald as a striate with crested muri and perforation. Although moderate variation in pollen size were found between $A$. dioicus $(13.57 \times 14.10 \mu \mathrm{m}$, Hebda et al., 1988b) and $A$. gombalanus (Walter) Fernald $(16.93 \times 16.60 \mu \mathrm{m}$, Zhou et al., 1999), detail pollen features of A. gombalanus were not observed by using SEM. To obtain additional clues and resolve the obscure interspecific delimitation within this genus, further morphological study of Aruncus pollen is necessary.

Here, we document detailed pollen morphology within the genus Aruncus based on SEM, to explore the potential taxonomic implications of pollen characters. We also identify the palynological characters that might be useful for taxa identification.

\section{Materials and Methods}

The present study was conducted on the 7 taxa ( 2 species, 5 varieties) of Aruncus. Most materials were taken from herbarium specimens from the following herbaria: $F, K B$, KHUS, NY, PE, TI and some plants were collected from natural populations in Korea. Specimen information for the taxa examined is summarized in the Table 1.

Pollen grains were prepared by critical point drying method. For morphological observation of pollen grains, dried flowers were first rehydrated with Agepon ${ }^{\circledR}$ (Agfa Gevaert, Leverkusen, Germany; Agepon wetting agent: distilled water, $1: 200)$ before dehydration to recover their original shape. The anthers were picked from flowers, and dehydrated through

Table 1. Voucher specimens of the genus Aruncus that were examined in the present study.

\begin{tabular}{|c|c|c|}
\hline Taxa & Voucher information & \\
\hline \multirow{4}{*}{$\begin{array}{l}\text { Aruncus dioicus L. var. dioicus (Walter) } \\
\text { Fernald }\end{array}$} & Korea, Seoul, Achasan Mt., 20 May 2014, Song and Ok 1800001 (KHUS) & $*$ \\
\hline & & \\
\hline & Korea, Gyeonggi-do, 20 May 2014, Song and Ok 050520 (KHUS) & \\
\hline & Korea, Gyeongsangnam-do, Namdeogyusan Mt., 17 Jun. 2006, Sun VP7400015156 (KB) & \\
\hline \multirow{2}{*}{$\begin{array}{l}\text { A. dioicus L. var. acuminatus (Douglas ex } \\
\text { Hook.) H.Hara }\end{array}$} & USA, Washington, 22 Jul. 1930, Aug. 1976, without collector's name (NY) & * \\
\hline & USA, Oregon, Lincoln Co., 11 Aug. 2007, Halse 7342 (F) & \\
\hline \multirow[t]{3}{*}{ A. dioicus L. var. aethusifolius (H.L,v.) H.Hara } & Korea, Jejudo Isl., Hallasan Mt., 09 Jul. 2012, Choi and Bum VP 0000422303 (KB) & $*$ \\
\hline & Korea, Jejudo Isl., Hallasan Mt., 15 Jul. 2014, Song and Ok 1800003 (KHUS) & \\
\hline & Korea, Jejudo Isl., Hallasan Mt., 15 Jul. 2014, Song and Ok 010714 (KHUS) & \\
\hline \multirow[t]{2}{*}{ A. dioicus L. var. astilboides (Maxim.) H.Hara } & $\begin{array}{l}\text { Japan, Hon-Shu, Hayachinesan Mt., Prox. Rikuchu, } 21 \text { Jul. 1913, without collector's name } \\
\text { M14-02(8) (TI) }\end{array}$ & $*$ \\
\hline & $\begin{array}{l}\text { Japan, Hon-Shu, Hayachinesan Mt., Prox. Rikuchu, } 6 \text { Aug. 1913, without collector's name } \\
\text { M14-02(10) (TI) }\end{array}$ & \\
\hline A. dioicus L. var. pubescens (Rydb.) Fernald & USA, St. Louis Co., 4 Jun 1926, Aug., 1976, without collector's name 1612 (F) & $*$ \\
\hline \multirow[t]{2}{*}{ A. dioicus L. var. vulgaris (Maxim.) H.Hara } & $\begin{array}{l}\text { USA, California, Siskiyou county, } 20 \text { Aug. 1959, Francia Chisaki, Helen K. Sharsmith } \\
\text { s.n. (NY) }\end{array}$ & $*$ \\
\hline & USA, Washington, 23 Jul. 1893, Sandberg and Leiberg 561 (F) & \\
\hline A. gombalanus (Hand.-Mazz.) Hand.-Mazz. & China, Mekong-Salween Divide, Sila, 5 Aug. 1938, T. T. Yu 00561083 (PE) & $*$ \\
\hline
\end{tabular}

Herbarium acronyms follow Index Herbariorum (Thiers, 2015); Asterisks indicate the used materials for figures and principal component analysis. 
an acetone series $(50 \%, 70 \%, 90 \%, 100 \%)$. The completely dehydrated anthers were critical-point-dried by using CP-dryer (SPI-13200J-AB, SPI Supplies, USA) and mounted on an aluminium stub with double adhesive tapes. The stubs were coated with gold using an ion-sputtering device (Cressington Sputter Coater 108, Ted Pella Inc., USA). The pollen grains were observed using a field emission scanning electron microscope (FE-SEM; JSM-7600F, JEOL, Japan) at an accelerating voltage of $10 \mathrm{kV}$ with working distance $8-10 \mathrm{~mm}$.

For each taxa, polar axis $(\mathrm{P})$, equatorial diameter $(\mathrm{E})$, equatorial diameter in polar view (EDPV), diameter between the apices of two ectocolpi (AC), polar area index (PAI), width of muri (WM) and width of grooves (WG), WM/WG ratio $(\mathrm{M} / \mathrm{G})$ of sexine ornamentation were measured on SEM images using Macnification software (version 2.0, Orbicule Inc, Leuven, Belgium). In particular, WM and WG were measured on the middle area of striation to exclude junction of striation.

Principal component analysis (PCA) was performed to verify whether the quantitative pollen data allowed the grouping of taxa. The first three principal components (PCs) with eigenvalues greater than 1 were represented. The results were presented in a two-dimensional plot of the first and second principal components. All analyses were done with statistical software $\mathrm{R}$ version 3.2.2 (R Development Core Team., 2015). We conducted an ANOVA to determine interspecific differences of principal component scores among the 7 taxa.

\section{Results and Discussion}

The pollen morphological characteristics are described below with regard to the following pollen features: size $(\mathrm{P}, \mathrm{E})$, shape $(\mathrm{P} / \mathrm{E})$, aperture number, equatorial diameter in polar view

Table 2. Pollen morphological characteristics of taxa within Aruncus.

\begin{tabular}{|c|c|c|c|c|c|c|c|c|c|c|c|}
\hline \multirow{2}{*}{ Taxon* } & \multirow{2}{*}{$n$} & \multicolumn{2}{|c|}{ Size } & \multirow{2}{*}{$\mathrm{P} / \mathrm{E}$} & \multicolumn{4}{|c|}{ Shape } & \multirow{2}{*}{ EDPV } & \multirow{2}{*}{$\mathrm{AC}$} & \multirow{2}{*}{ PAI } \\
\hline & & $\mathrm{P}(\mu \mathrm{m})$ & $\mathrm{E}(\mu \mathrm{m})$ & & $\mathrm{SO}$ & OS & $\mathrm{S}$ & PS & & & \\
\hline \multirow[t]{3}{*}{ A. dioicus var. dioicus } & 30 & $\begin{array}{c}10.46 \pm 0.70 \\
(9.29-11.90)\end{array}$ & $\begin{array}{c}12.23 \pm 0.77 \\
(10.54-13.44)\end{array}$ & $\begin{array}{c}0.86 \pm 0.03 \\
(0.80-0.92)\end{array}$ & ++ & + & - & - & $\begin{array}{c}11.78 \pm 0.37 \\
(10.99-12.47)\end{array}$ & $\begin{array}{c}4.06 \pm 1.51 \\
(3.26-4.48)\end{array}$ & $0.32 \pm 0.03$ \\
\hline & 10 & $\begin{array}{c}10.76 \pm 0.66 \\
(9.25-12.30)\end{array}$ & $\begin{array}{c}12.40 \pm 0.51 \\
(11.48-13.29)\end{array}$ & $\begin{array}{c}0.87 \pm 0.04 \\
(0.81-0.95)\end{array}$ & ++ & + & - & - & $\begin{array}{c}11.90 \pm 0.49 \\
(10.97-12.83)\end{array}$ & $\begin{array}{c}3.80 \pm 0.31 \\
(3.04-4.40)\end{array}$ & $0.32 \pm 0.03$ \\
\hline & 10 & $\begin{array}{c}10.56 \pm 0.74 \\
(9.25-11.60)\end{array}$ & $\begin{array}{c}12.29 \pm 0.58 \\
(11.48-13.29)\end{array}$ & $\begin{array}{c}0.87 \pm 0.03 \\
(0.81-0.93)\end{array}$ & ++ & + & - & - & $\begin{array}{c}12.55 \pm 0.59 \\
(11.34-13.84)\end{array}$ & $\begin{array}{c}4.03 \pm 0.30 \\
(3.33-4.56)\end{array}$ & $0.32 \pm 0.03$ \\
\hline \multirow[t]{2}{*}{ A. dioicus var. acuminatus } & 30 & $\begin{array}{c}10.12 \pm 0.55 \\
(9.23-11.52)\end{array}$ & $\begin{array}{c}10.46 \pm 0.50 \\
(9.64-11.43)\end{array}$ & $\begin{array}{c}0.97 \pm 0.04 \\
(0.86-1.05)\end{array}$ & - & ++ & + & + & $\begin{array}{c}10.13 \pm 0.43 \\
(9.26-11.13)\end{array}$ & $\begin{array}{c}3.19 \pm 1.52 \\
(2.11-4.25)\end{array}$ & $0.29 \pm 0.05$ \\
\hline & 10 & $\begin{array}{c}9.89 \pm 0.55 \\
(8.97-10.97)\end{array}$ & $\begin{array}{c}10.44 \pm 0.58 \\
(9.24-11.66)\end{array}$ & $\begin{array}{c}0.95 \pm 0.05 \\
(0.87-1.08)\end{array}$ & + & ++ & - & + & $\begin{array}{c}9.88 \pm 0.37 \\
(9.37-10.50)\end{array}$ & $\begin{array}{c}2.94 \pm 0.36 \\
(2.32-3.72)\end{array}$ & $0.30 \pm 0.04$ \\
\hline \multirow[t]{3}{*}{ A. dioicus var. aethusifolius } & 30 & $\begin{array}{c}11.60 \pm 0.41 \\
(10.58-12.57)\end{array}$ & $\begin{array}{c}13.18 \pm 0.69 \\
(12.15-14.40)\end{array}$ & $\begin{array}{c}0.88 \pm 0.04 \\
(0.81-0.96)\end{array}$ & + & ++ & - & - & $\begin{array}{c}12.75 \pm 0.40 \\
(11.63-13.42)\end{array}$ & $\begin{array}{c}3.66 \pm 1.79 \\
(2.45-4.24)\end{array}$ & $0.26 \pm 0.04$ \\
\hline & 10 & $\begin{array}{c}11.41 \pm 0.48 \\
(10.62-12.12)\end{array}$ & $\begin{array}{c}12.97 \pm 0.79 \\
(11.66-14.26)\end{array}$ & $\begin{array}{c}0.88 \pm 0.04 \\
(0.79-0.96)\end{array}$ & + & ++ & - & - & $\begin{array}{c}13.42 \pm 0.82 \\
(11.83-14.37)\end{array}$ & $\begin{array}{c}3.94 \pm 0.39 \\
(3.49-4.66)\end{array}$ & $0.29 \pm 0.03$ \\
\hline & 10 & $\begin{array}{c}11.32 \pm 0.61 \\
(10.21-12.30)\end{array}$ & $\begin{array}{c}12.80 \pm 0.68 \\
(11.70-13.96)\end{array}$ & $\begin{array}{c}0.88 \pm 0.05 \\
(0.78-0.98)\end{array}$ & + & + & - & - & $\begin{array}{c}13.45 \pm 0.79 \\
(12.17-15.33)\end{array}$ & $\begin{array}{c}4.07 \pm 0.42 \\
(3.16-4.93)\end{array}$ & $0.30 \pm 0.03$ \\
\hline \multirow[t]{2}{*}{ A. dioicus var. astilboides } & 30 & $\begin{array}{c}10.84 \pm 0.70 \\
(9.99-12.39)\end{array}$ & $\begin{array}{c}11.80 \pm 0.70 \\
(10.64-13.65)\end{array}$ & $\begin{array}{c}0.92 \pm 0.05 \\
(0.84-1.05)\end{array}$ & + & ++ & + & + & $\begin{array}{c}11.43 \pm 0.50 \\
(10.10-12.38)\end{array}$ & $\begin{array}{c}4.01 \pm 0.49 \\
(2.98-5.18)\end{array}$ & $0.35 \pm 0.04$ \\
\hline & 10 & $\begin{array}{c}10.74 \pm 0.76 \\
(9.73-12.22)\end{array}$ & $\begin{array}{c}11.47 \pm 0.76 \\
(10.44-13.01)\end{array}$ & $\begin{array}{c}0.94 \pm 0.06 \\
(0.81-1.06)\end{array}$ & + & ++ & - & + & $\begin{array}{c}11.04 \pm 1.07 \\
(9.20-12.85)\end{array}$ & $\begin{array}{c}3.61 \pm 0.43 \\
(2.29-4.28)\end{array}$ & $0.33 \pm 0.05$ \\
\hline A. dioicus var. pubescens & 30 & $\begin{array}{c}9.88 \pm 0.86 \\
(8.33-12.34)\end{array}$ & $\begin{array}{c}10.63 \pm 0.75 \\
(8.93-12.72)\end{array}$ & $\begin{array}{c}0.93 \pm 0.06 \\
(0.84-1.06)\end{array}$ & + & ++ & - & + & $\begin{array}{c}10.04 \pm 0.65 \\
(8.40-11.56)\end{array}$ & $\begin{array}{c}2.86 \pm 0.53 \\
(1.00-3.85)\end{array}$ & $0.29 \pm 0.04$ \\
\hline \multirow[t]{2}{*}{ A. dioicus var. vulgaris } & 30 & $\begin{array}{c}10.06 \pm 0.61 \\
(8.90-11.45)\end{array}$ & $\begin{array}{c}11.08 \pm 0.61 \\
(9.99-12.46)\end{array}$ & $\begin{array}{c}0.91 \pm 0.05 \\
(0.84-1.02)\end{array}$ & + & ++ & - & + & $\begin{array}{c}10.77 \pm 0.66 \\
(9.43-11.94)\end{array}$ & $\begin{array}{c}3.80 \pm 0.55 \\
(2.00-4.66)\end{array}$ & $0.36 \pm 0.03$ \\
\hline & 10 & $\begin{array}{c}10.20 \pm 0.68 \\
(8-79-11.30)\end{array}$ & $\begin{array}{c}11.18 \pm 0.77 \\
(9.58-13.38)\end{array}$ & $\begin{array}{c}0.91 \pm 0.05 \\
(0.83-1.00)\end{array}$ & + & ++ & + & - & $\begin{array}{c}11.20 \pm 0.84 \\
(9.8-13.17)\end{array}$ & $\begin{array}{c}3.95 \pm 0.64 \\
(2.86-5.23)\end{array}$ & $0.35 \pm 0.06$ \\
\hline A. gombalanus & 30 & $\begin{array}{c}10.74 \pm 0.63 \\
(9.74-11.92)\end{array}$ & $\begin{array}{c}11.42 \pm 0.69 \\
(9.84-12.75)\end{array}$ & $\begin{array}{c}0.94 \pm 0.06 \\
(0.84-1.10)\end{array}$ & + & ++ & + & + & $\begin{array}{c}10.61 \pm 0.62 \\
(9.78-12.44)\end{array}$ & $\begin{array}{c}3.57 \pm 1.13 \\
(2.49-4.44)\end{array}$ & $0.32 \pm 0.05$ \\
\hline
\end{tabular}

Numbers refer to mean \pm standard deviation (minimum-maximum); Mean \pm standard deviation only in PAI; Polar axis (P); Equatorial diameter (E); Suboblate (SO); Oblate spheroidal (OS); Spheroidal (S); Prolate-spheroidal (PS); Absent (-); Present (+); Dominant (++); Equatorial diameter in polar view (EDPV); Diameter between the apices of two ectocolpi (AC); Polar area indices (PAI), *Order of taxa was consistent with Table 1. 


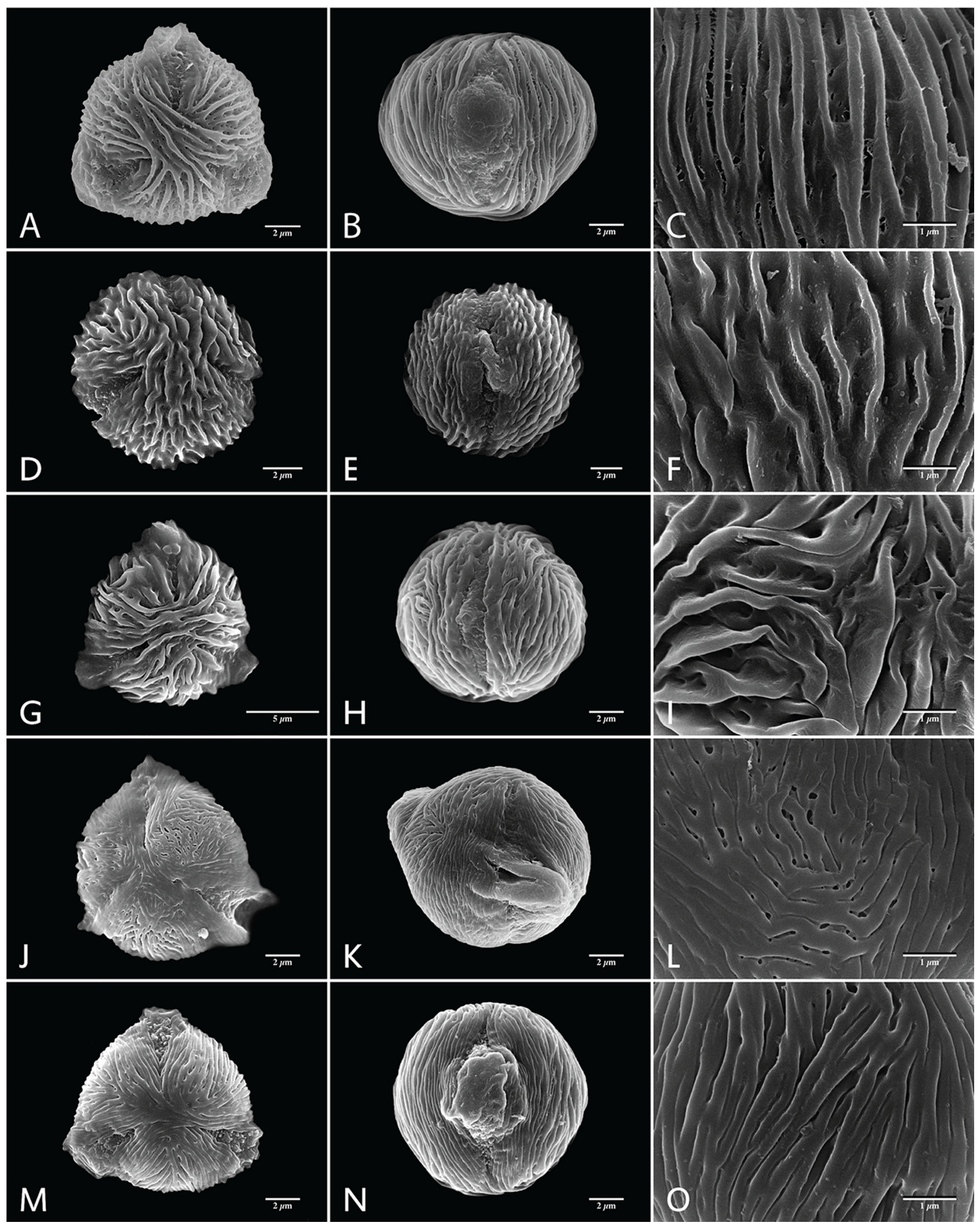

Fig. 1. SEM micrographs of Aruncus pollen grains (with striate-perforate sexine ornamentation). A-C, Aruncus dioicus var. dioicus; D-F, A. dioicus var. acuminatus; G-I, A. dioiucs var. astilboides; J-L, A. dioicus var. pubescens; M-O, A. dioicus var. vulgaris; A, D, G, J, M, Polar view of pollen grains; B, E, H, K, N, Equatorial view of pollen grains; C, F, I, L, O Sexine ornamentation at mesocolpium. 

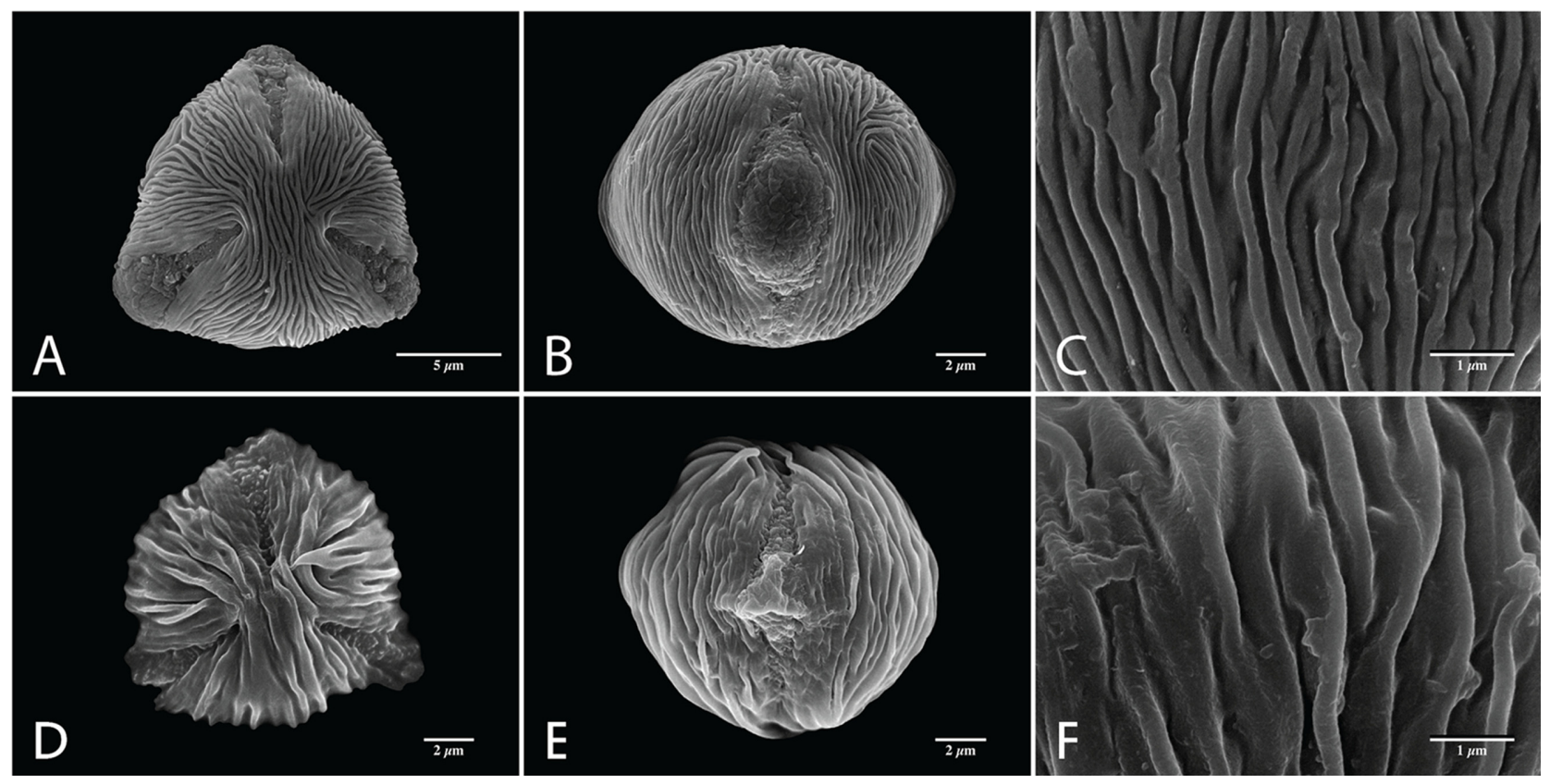

Fig. 2. SEM micrographs of Aruncus pollen grains (with striate-psilate sexine ornamentation). A-C, A. dioicus var. aethusifolius; D-F, A. gombalanus; A, D, Polar view of pollen grains; B, E, Equatorial view of pollen grains; C, F, Sexine ornamentation at mesocolpium.

(EDPV), diameter between the apices of two ectocolpi (AC), polar area index (PAI), and sexine ornamentation. The representative pollen characters are summarized in Tables 23 and illustrated in Figures 1-2.

Pollen grains are monad and mostly small in size $(\mathrm{P}=8.33-$ $12.57 \mu \mathrm{m}, \mathrm{E}=8.93-14.40 \mu \mathrm{m}$; Table 2). A. dioicus var. pubescens having the smallest pollen grains, of all taxa investigated (a mean value of $\mathrm{P} \times \mathrm{E}$ was $9.88 \times 10.63 \mu \mathrm{m})$, and $A$. dioicus var. aethusifolius having the largest $(11.60 \times 13.18 \mu \mathrm{m})$. The shape of the pollen grains is sub-circular to circular, or rarely semi-angular in polar view, and ranges from suboblate to prolate-sheperoidal in equatorial view $(\mathrm{P} / \mathrm{E}=0.68-1.70$; Figs. 1, 2, Table 2). Most taxa have predominantly oblate-spheroidal pollen grains. The exception is $A$. dioicus var. dioicus, which has mostly sub-oblate pollen grains. All pollen grains studied were tri-colporate, the simple colpi are distributed symmetrically, elongated, and narrowed toward the poles with granular aperture membranes (Figs. 1, 2; Table 2). The apocolpium was rather narrow, with lower PAI value ranging from 0.26 to 0.36 (Table 2). A. dioicus var. aethusifolius had the lowest value (0.26), and A. dioicus var. vulgaris had the highest (0.36).

The pollen grains examined in this study were consistently smaller than those examined in previous Aruncus pollen studies. In a previous study of $A$. dioicus, the average size of pollen grains was $13.57 \times 14.10 \mu \mathrm{m}$ (Hebda et al., 1988a); for A. gombalanus, the previously described average was $16.93 \times 16.60 \mu \mathrm{m}$ (Zhou et al., 1999). The present results for the same taxa were $10.46 \times 12.23 \mu \mathrm{m}$ and $10.74 \times 11.42 \mu \mathrm{m}$, respectively. All previous studies are based on acetolysed material, whereas the present study treated using the critical point drying process. The use of different preparation techniques is known to affect the size and shape of pollen grains, with grains that are treated using critical point drying always being smaller than acetolysed grains (Reitsma, 1969, Moon et al., 2008). Because the acetolysis method can destroy the colpus membranes, the size and shape of the pollen grains is modified, whereas the critical point drying maintains these natural features (Demissew and Harley, 1992).

Sexine ornamentation of the pollen grains was consistently striate, consisting of muri and grooves with or without microperforations on the grooves. The width of striae varied, with the largest values of muri and grooves observed in $A$. dioicus and A. dioicus var. astilboides pollen grains, respectively (Table 3 ). The striate-microperforate pattern can be subdivided into two patterns based on the widths of muri and grooves (Fig. 1). A pattern with wider muri than grooves was found in $A$. dioicus var. pubescens (Fig. $1 \mathrm{~J}-\mathrm{L}$ ) and $A$. dioicus var. vulgaris (Fig. 1M-O), whereas A. dioicus var. dioicus (Fig. 1A-C), A. dioicus var. acuminatus (Fig. 1D-F), and A. dioicus var. astilboides (Fig. 1G-I) possess wider grooves than muri. The striate-psilate pattern can also be subdivided into two patterns based on relative widths of muri and grooves (Fig. 2). A. dioicus var. aethusifolius has wider muri than grooves (Fig. 2A-C), whereas A. gombalanus has 
muri and grooves of a similar width (Fig. 2D-F). More specifically, the direction and length of the striae (muri and grooves) patterns in the mesocolpium are variable among the Aruncus taxa. The muri are prominently formed in A. dioicus var. dioicus, A. dioicus var. acuminatus, A. dioicus var. astilboides, and A. gombalanus, with relatively short, and sharply crested muri being a distinct feature of $A$. dioicus var. acuminatus. Striae tend to be parallel with the colpus, but often displayed a looped shape on or near the poles and/or mesocolpium in most taxa. However, the muri of $A$. dioicus var. astilboides are branched, anastomosed, wiggly and parallel to aperture at mesocolpium (Fig. 1I).

The sexine ornamentation has provided useful characters for delimiting genera and species in Rosaceae (Ueda and Tomita, 1989; Ueda, 1992; Hebda and Chinnappa, 1994; Chung et al., 2010; Wroñska-Pilarek and Jagodziñski, 2011; Shi et al., 2013). In the present study, considerable variation in sexine ornamentation was observed between the studied taxa. As shown in earlier studies, the striate-perforate pattern is a common feature in genus Aruncus (Hebda et al. 1988a). However, we observed additional sexine ornamentation patterns such as striate-psilate (Fig. 2). Moreover, detailed ornamentation characteristic, such as width of striae (muri and grooves), are informative within the genus Aruncus. For example, A. dioicus var. acuminatus has a unique sexine ornamentation pattern, with sharply crested, relatively short length of muri. Such features could be applicable as identifying and diagnostic characters for the taxa within the genus Aruncus. Further, the fine variations in sexine ornamentation, such as the thickness or pattern of striae, may provide additional taxonomic significance among the taxa. Therefore, more detailed study of pollen wall stratification through transmission electronic microscope (TEM) is required. Such study may be helpful in elucidating the infrageneric relationships between Aruncus taxa.

Statistical methods such as PCA have been used to evaluate the systematic usefulness of pollen data (Akhila and Beevy, 2015; de Abreu et al., 2015; da Luz et al., 2015; MezzonatoPires et al., 2015). In the present study, PCA was used to explore the relationships between taxa. Three principle components (PCs), with eigenvalues larger than 1, explained $74.6 \%$ of the variation in the data (Figs. 3-4; Table 4). The PC1 explains $31.1 \%$ of the variance based on the pollen size $(\mathrm{P}, \mathrm{E})$, and diameter between the apices of two ectocolpi (AC). The PC2 accounts for $22.4 \%$ of the data variability mostly related to shape $(\mathrm{P} / \mathrm{E})$ and sexine ornamentation characteristic such as width of muri (WM) and WM/WG ratio (M/G). $A$. dioicus var. dioicus, $A$. dioicus var. aethusifolius and $A$. dioicus var. astilboides were grouped on the positive side of the PC1 axis based on their relatively larger pollen grains (Figs. 3, 4A). Four taxa (A. dioicus var. acuminatus, $A$. dioicus var. aethusifolius, A. dioicus var. astilboides, and A. gombalanus)

Table 3. The characteristics of sexine ornamentation within Aruncus taxa.

\begin{tabular}{|c|c|c|c|c|c|}
\hline \multirow{2}{*}{ Taxon* } & \multirow{2}{*}{$\mathrm{n}$} & \multicolumn{2}{|c|}{ Width of } & \multirow{2}{*}{$\mathrm{M} / \mathrm{G}$} & \multirow{2}{*}{ Perforate } \\
\hline & & Muri & Grooves & & \\
\hline \multirow[t]{3}{*}{ A. dioicus var. dioicus } & 30 & $0.25 \pm 0.04(0.20-0.35)$ & $0.33 \pm 0.07(0.23-0.51)$ & - & + \\
\hline & 10 & $0.20 \pm 0.06(0.14-0.36)$ & $0.34 \pm 0.10(0.24-0.59)$ & - & + \\
\hline & 10 & $0.27 \pm 0.06(0.17-0.37)$ & $0.39 \pm 0.06(0.31-0.47)$ & - & + \\
\hline \multirow[t]{2}{*}{ A. dioicus var. acuminatus } & 30 & $0.12 \pm 0.03(0.07-0.18)$ & $0.31 \pm 0.09(0.21-0.58)$ & - & + \\
\hline & 10 & $0.15 \pm 0.03(0.10-0.21)$ & $0.40 \pm 0.11(0.20-0.61)$ & - & + \\
\hline \multirow[t]{3}{*}{ A. dioicus var. aethusifolius } & 30 & $0.21 \pm 0.04(0.14-0.30)$ & $0.13 \pm 0.03(0.07-0.19)$ & + & - \\
\hline & 10 & $0.22 \pm 0.03(0.16-0.28)$ & $0.11 \pm 0.03(0.06-0.17)$ & + & - \\
\hline & 10 & $0.25 \pm 0.04(0.21-0.33)$ & $0.12 \pm 0.03(0.06-0.15)$ & + & - \\
\hline \multirow[t]{2}{*}{ A. dioicus var. astilboides } & 30 & $0.16 \pm 0.02(0.12-0.20)$ & $0.43 \pm 0.10(0.26-0.65)$ & - & + \\
\hline & 10 & $0.23 \pm 0.04(0.17-0.30)$ & $0.46 \pm 0.10(0.32-0.62)$ & - & + \\
\hline A. dioicus var. pubescens & 30 & $0.20 \pm 0.04(0.12-0.27)$ & $0.05 \pm 0.02(0.03-0.09)$ & + & + \\
\hline \multirow[t]{2}{*}{ A. dioicus var. vulgaris } & 30 & $0.25 \pm 0.07(0.14-0.41)$ & $0.05 \pm 0.02(0.03-0.09)$ & + & + \\
\hline & 10 & $0.26 \pm 0.04(0.16-0.33)$ & $0.06 \pm 0.02(0.03-0.14)$ & + & + \\
\hline A. gombalanus & 30 & $0.25 \pm 0.05(0.18-0.39)$ & $0.28 \pm 0.06(0.19-0.42)$ & \pm & - \\
\hline
\end{tabular}

Numbers refer to mean \pm standard deviation (minimum-maximum) $\mu \mathrm{m}$; Muri (M); Grooves (G); Width of muri/Width of grooves (M/G) $<1$ : -, $>1$ :,$+ \geq 1$ : \pm ; Absent (-); Present (+), ${ }^{*}$ Order of taxa was consistent with Table1. 
with similar shape, narrow muri (small WM value), and a small $\mathrm{M} / \mathrm{G}$ ratio were positioned on the positive side of the $\mathrm{PC} 2$ axis; others were grouped on negative (Figs. 3, 4B). Also, the equatorial diameter in polar view (EDPV), Polar area indices (PAI), and width of grooves (WG) related variables included in PC3. Two taxa: A. dioicus var. aethusifolius, A. dioicus var. pubescens were distributed on the positive side of PC3 (Figs. 3, 4C).

In the PCA of the pollen characters, PC1 best explained the variability of pollen size while the sexine ornamentation features were explained by PC2 and PC3 (Table 4). All differences between the taxa were significant. Thus, the pollen morphological characteristic should be useful for identification of taxa in the genus Aruncus. Although the scattered plot of A. dioicus var. dioicus was partially overlapped by that of another species $A$. gombalanus, the infraspecies of $A$. dioicus were separated into two groups. One group was overlapped by $A$. dioicus, and the other was distinguished from $A$. dioicus. Therefore, to clarify the relationship btween Aruncus taxa, more detailed taxonomical study is needed.

A. dioicus var. aethusifolius, endemic to Korea, is differentiated by deeply incised leaflet. Its distribution is restricted to Hallasan Mt. on Jeju Is. Although Nakai designated $A$. aethusifolius as an independent species within the genus in 1912, Hara (1955) recognized it as a variety of A. dioicus (Hara, 1955). According to the present study, $A$. dioicus var. dioicus and $A$. diocus var. aethusifolius showed considerable distance in palynological characteristics such as pollen size and sexine ornamentation. In particular, sexine ornamentation was striate-perforate in $A$. dioicus and all of its infrageneric taxa except $A$. diocus var. aethusifolius, which instead exhibited a striate-psilate pattern like A. gombalanus. This suggest that palynological characteristics could provide evidence to aid in taxonomical delimitation of this taxon. To confirm the taxonomical rank of $A$. diocus var. aethusifolius, further study is necessary.

In summary, this study provides additional pollen morphological data for the genus Aruncus. The pollen grains

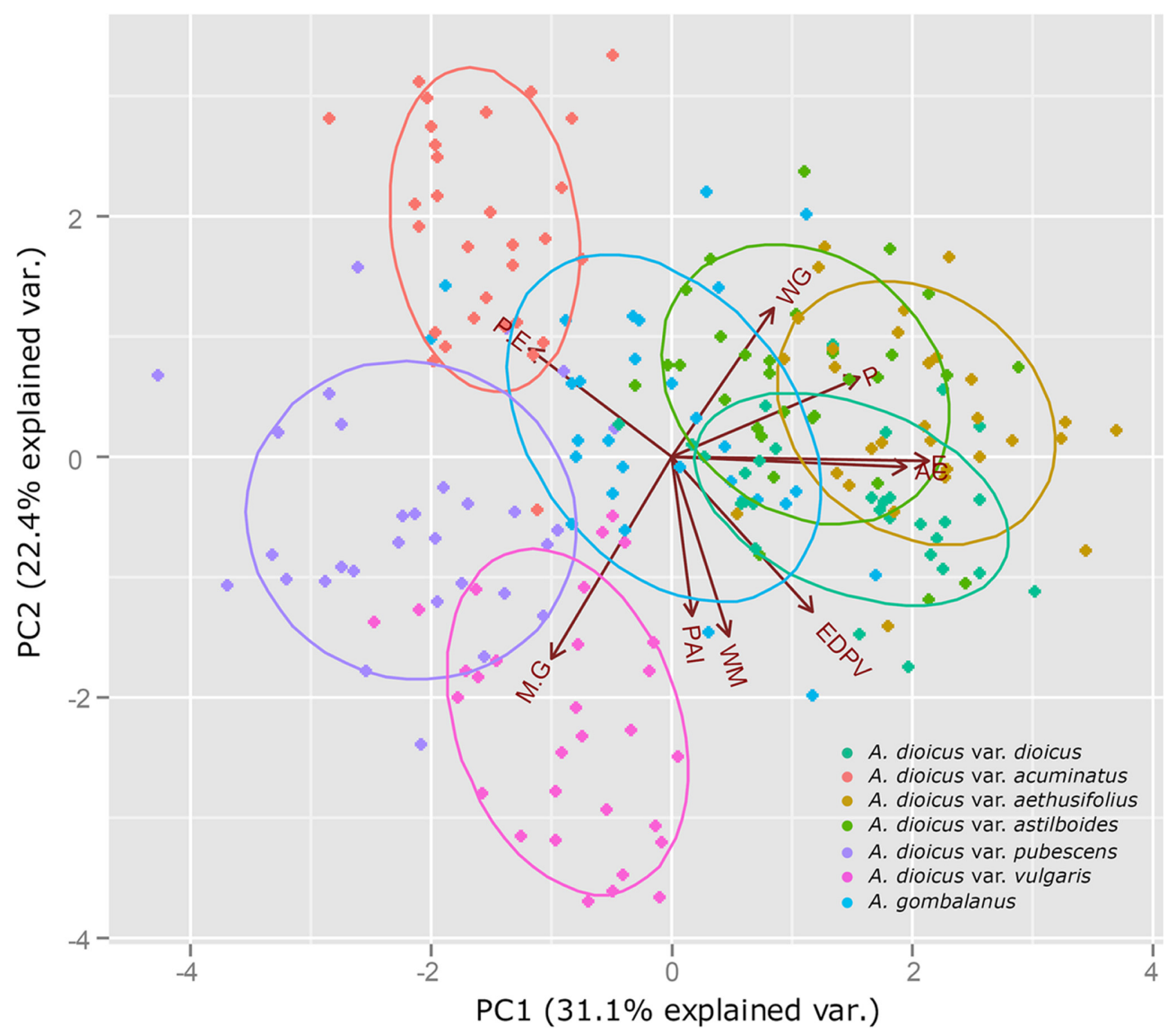

Fig. 3. Scatter plot of the principal component analysis for pollen morphological characteristics in Aruncus taxa. The first two principal components were plotted and each color represents a different taxa; Polar axis (P); Equatorial diameter (E); P/E ratio (P.E); Equatorial diameter in polar view (EDPV); Apocolpus side (AS); Polar area indexes (PAI); Width of muri (WM) and width of grooves (WG); WM/WG ratio (M/G); The arrows are displayed for variables. 


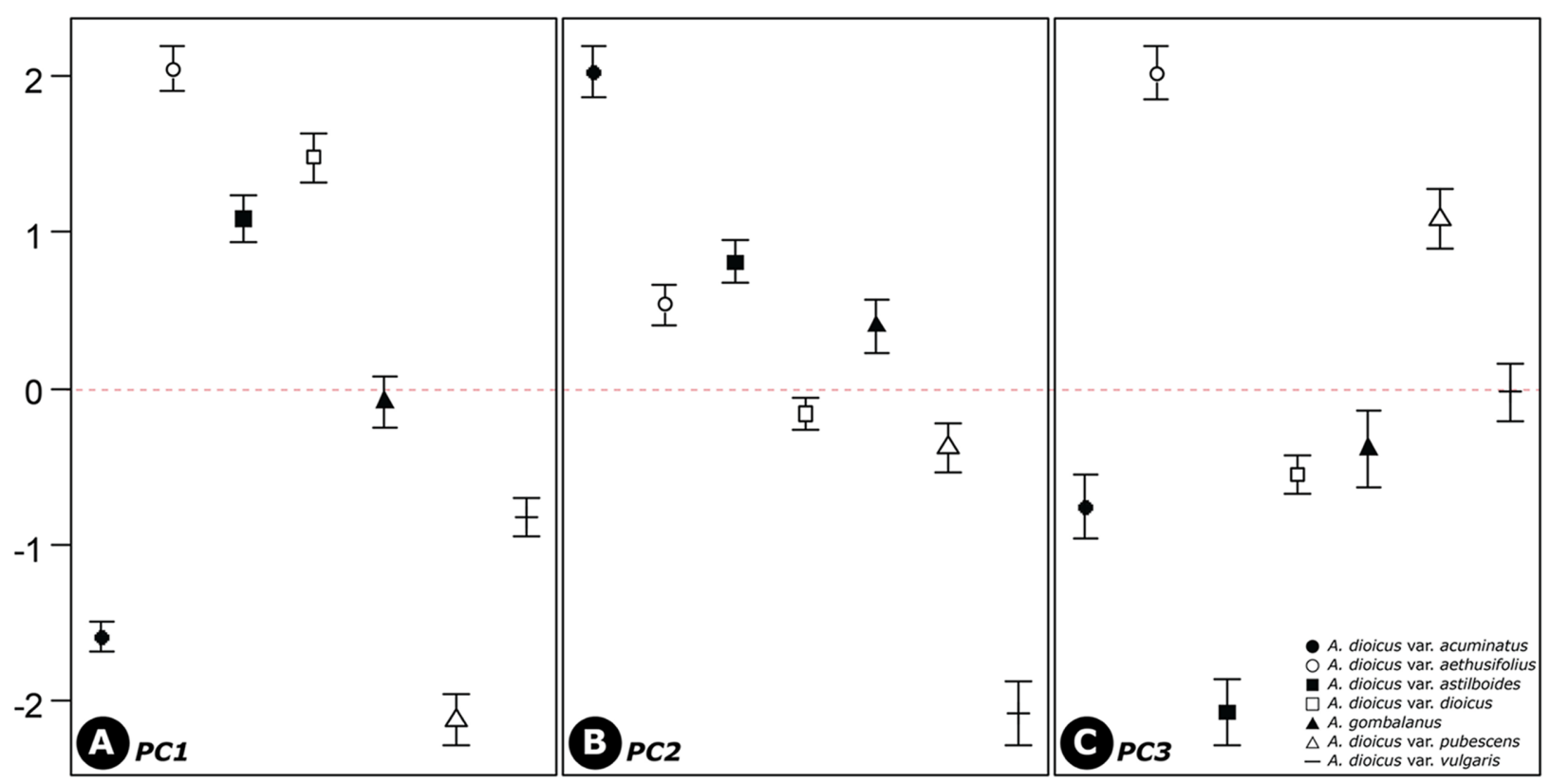

Fig. 4. Comparison of the three component scores of pollen characteristics among the taxa. Dots in the middle and error bars denote the average and standard error of component scores, respectively. All differences were significant.

Table 4. Variable loadings of pollen morphological characters of Aurnucs for three principal components. The first three PCs with eigenvalue larger than one were represented here. Each percentage in parenthesis indicates the amount of variation explained by each PC, and the components that were loaded most highly for each variable are in bold.

\begin{tabular}{cccc}
\hline \hline Variables & PC1 $(31.1 \%)$ & PC2 $(22.4 \%)$ & PC3 $(21.2 \%)$ \\
\hline P & $\mathbf{0 . 3 9 7 3 4 9 0 9}$ & 0.18989358 & 0.21148638 \\
E & $\mathbf{0 . 5 3 7 2 9 0 3 5}$ & -0.03983447 & 0.2384708 \\
P/E & -0.29225047 & $\mathbf{0 . 3 0 3 7 2 2 5 3}$ & -0.07963313 \\
EDPV & 0.30045671 & -0.34309789 & $\mathbf{- 0 . 4 8 9 5 2 1 9 2}$ \\
AC & $\mathbf{0 . 4 9 6 3 4 4 2 5}$ & -0.03779548 & 0.16760828 \\
PAI & 0.04758188 & -0.34603765 & $\mathbf{- 0 . 5 9 7 4 7 8 2 7}$ \\
WM & 0.11037634 & $\mathbf{- 0 . 4 5 2 8 4 3 2 2}$ & 0.16012831 \\
WG & 0.22042085 & 0.39749682 & $\mathbf{- 0 . 4 1 2 9 0 3 7 5}$ \\
M/G & -0.26145415 & $\mathbf{- 0 . 5 1 7 8 3 0 9}$ & 0.26688695 \\
\hline
\end{tabular}

Polar axis (P); Equatorial diameter (E); P/E ratio (P/E); Equatorial diameter in polar view (EDPV); Diameter between the apices of two ectocolpi (AC); Polar area indices (PAI); Width of muri (WM); Width of grooves (WG); WM/WG ratio (M/G)

are small, tri-colporate, and sub-oblate to prolate-spheroidal in shape. They show striate sexine ornamentation, but there is significant variation in the shape and thickness of striae between taxa. Although further study of Aruncus is necessary to clarify the taxonomic delimitation of its taxa, in this study, palynological characteristics of Aruncus did illustrate some of the variation within and between the studied taxa.

\section{Acknowledgments}

We are grateful to our colleagues H.-K. Moon, M.-J. Kong and J.-H. Song for helping us in various ways. This research was supported by the Basic Science Research Program through the National Research Foundation of Korea (NRF) funded by the Ministry of Education, Sciences and Technology (NRF2012R1A1A2004149) to S.-P. Hong.

\section{Literature Cited}

Akhila, H. and S. S. Beevy. 2015. Palynological characterization of species of Sesamum (Pedaliaceae) from Kerala: a systematic approach. Plant Systematics and Evolution 301: 21792188.

Chung, K. S., W. J. Elisens and J. J. Skvarla. 2010. Pollen morphology and its phylogenetic significance in tribe Sanguisorbeae (Rosaceae). Plant Systematics and Evolution 285: 139148.

da Luz, C. F. P., V. L. dos Santos, J. S. Guedes, G. de Oliveira Silva-Cobra and M. D. G. L. Wanderley. In press. Pollen morphology of some Brazilian Xyris Gronov. ex L. (Xyridaceae) species. Brazilian Journal of Botany.

de Abreu, V. H. R., J. da Conceição Santos, R. L. Esteves and V. Gonçalves-Esteves. 2015. Pollen morphology of Praxelis (Asteraceae, Eupatorieae, Praxelinae) in Brazil. Plant Systematics and Evolution 301: 599-608.

Demissew, S. and M. Harley. 1992. Trichome, seed surface and 
pollen characters in Stachys (Lamioideae: Labiatae) in tropical Africa. In Advances in Labiate Science. Harley, R. M. and T. Reynolds (eds.), Royal Botanic Gardens, Kew, UK. Pp. 149-166.

Eide, F. 1981. Key for northwest European Rosaceae pollen. Grana 20: 101-118.

Erdtman, G. 1960. The acetolysis method: a revised description. Svensk Botanisk Tidskrift Utgifven af Svenska Botaniska Foreningen. 54: 561-564.

Hara, H. 1955. Critical notes on some type specimens of East-Asiatic plants in foreign herbaria. Journal of Japanese Botany 30 : 138-141.

Hebda, R. J. and C. C. Chinnappa. 1990a. Pollen morphology of the Rosaceae of Western Canada. III. Geum. Canadian Journal of Botany 68: 1369-1378.

Hebda, R. J. and C. C. Chinnappa. 1990b. Studies on pollen morphology of Rosaceae in Canada. Review of Palaeobotany and Palynology 64: 103-108.

Hebda, R. J., C. C. Chinnappa and B. M. Smith. 1988a. Pollen morphology of the Rosaceae of Western Canada. I. Agrimonia to Crataegus. Grana 27: 95-113.

Hebda, R. J., C. C. Chinnappa and B. M. Smith. 1988b. Pollen morphology of the Rosaceae of Western Canada. II. Dryas, Fragaria, Holodiscus. Canadian Journal of Botany 66: 595612.

Hebda, R. J. and C. C. Chinnappa. 1994. Studies on pollen morphology of Rosaceae. Acta Botanica Gallica 141: 183-193.

Ikeda, H. 1995. Aruncus L. In Flora of Japan. Iwatsuki, D. E. Boufford and H. Ohba. (eds.), Vol. Ilb: Angiospermae; Dicotyledonieae; Archichlamideae (b). Kodansha, Ltd., Tokyo. Pp. 100-102.

Lee, S. T., K. I. Heo, J. H. Cho, C. H. Lee, W. Chen and S. C. Kim. 2011. New insights into pollen morphology and its implications in the phylogeny of Sanguisorba L. (Rosaceae; Sanguisorbeae). Plant Systematics and Evolution 291: 227242.

Mellichamp, T. L. 1976. A comparative study of Aruncus (Rosaceae) and Astilbe (Saxifragaceae), and the problem of their relationships. Ph.D. Thesis, University of Michigan, USA. 180 P.

Mezzonato-Pires, A. C., M. A. Milward-de-Azevedo, C. B. F. Mendonça and V. Gonçalves-Esteves. 2015. Pollen morphology and detailed sexine of Passiflora subgenus Astrophea (Passifloraceae). Plant Systematics and Evolution 301: 2189-2202.
Moon, H. K., S. Vinckier, E. Smets and S. Huysmans. 2008. Comparative pollen morphology and ultrastructure of Mentheae subtribe Nepetinae (Lamiaceae). Review of Palaeobotany and Palynology 149: 174-198.

Naruhashi, N. and Y. Toyoshima. 1979. Pollen morphology of Japanese Rosaceae. Journal of Phytogeography and Taxonomy 27: 46-50. (in Japanese)

Potter, D., T. Eriksson, R. C. Evans, S. Oh, J. Smedmark, D. R. Morgan, M. Kerr, K. R. Robertson, M. Arsenault and T. A. Dickinson. 2007. Phylogeny and classification of Rosaceae. Plant Systematics and Evolution 266: 5-43.

Reitsma, T. 1966. Pollen morphology of some European Rosaceae. Acta Botanica Neerlandica 15: 290-307.

Reitsma, T. 1969. Size modification of recent pollen grains under different treatments. Review of Palaeobotany and Palynology 9: $175-202$.

Shi, W., J. Wen and S. Lutz. 2013. Pollen morphology of the Maddenia clade of Prunus and its taxonomic and phylogenetic implications. Journal of Systematics and Evolution 51: 164183.

Thakur, D. and S. Thakur. 1970. Pollen morphology and germination in some temperate drupe plants. Journal of Palynology 6 : 96-100.

The Plant List. 2013. Version 1.1. Published on the Internet. Retrieved October 2015, from http://www.theplantlist.org/

Thiers, B. 2015. Index Herbarium: A global directory of public herbaria and associated staff. New York Botanical Garden's Virtual Herbarium. Retrieved October 2015, from http:// sweetgum.nybg.org/science/ih/.

Tutin, T. G. 1964. Aruncus L. In Flora Europaea. Tutin, T. G., V. H. Heywood, N. A. Burges, D. M. Moore, D. H. Valentine, S. M. Walters and D. A. Webb. (eds.), Vol. 2: Rosaceae to Umbelliferae Cambridge University Press, Cambridge. Pp. 3-6.

Ueda, Y. 1992. Pollen surface morphology in the genus Rosa and related genera. Japanese Journal of Palynology 38: 94-105.

Ueda, Y. and H. Tomita. 1989. Morphometric analysis of pollen exine patterns in roses. Journal of the Japanese Society for Horticultural Science 581: 211-220.

Wroñska-Pilarek, D. and A. M. Jagodziñski. 2011. Systematic importance of pollen morphological features of selected species from the genus Rosa (Rosaceae). Plant Systematics and Evolution 295: 55-72.

Zhou, L., Z. Wei and Z. Wu. 1999. Pollen morphology of Spiraeoideae in China (Rosaceae). Acta Botanica Yunnanica 21: 303-308. (in Chinese) 